\title{
ENTREPRENEUR
}

Jurnal Bisnis Manajemen Dan Kewirausahaan

Program Studi Manajemen Fakultas Ekonomika dan Bisnis Universitas Majalengka Published every January and July e-ISSN : (Proses), p-ISSN: 2723-1941 Available online https://ejournal.unma.ac.id/index.php/entrepreneur

\section{Pengaruh Profitabilitas, Leverage dan Ukuran Perusahaan Terhadap Nilai Perusahaan Pada Perusahaan Makanan dan Minuman Yang Terdaftar di Bei Tahun 2014-2018}

\author{
Wulan Riyadi \\ Fakultas Ekonomika dan Bisnis Universitas Majalengka \\ wulanriyadi@unma.ac.id
}

\begin{abstract}
.
A good company can be seen from the corporate value, currently business competition between companies is very tight so it can't be separated from social, political, technologi and economic depelopment. The company must be more effective and efficient in carrying out the company's operational activities as well as improving performance and innovating by increasing shareholder prosperity and to increase company growth through increasing corporate value.

In this study profitability is measured using Return On Assets (ROA), leverage is measured using a Debt to Equity Ratio (DER), firm size is measured using Ln Assets and corporate value is measured using Tobin's $Q$. The purpose of this study was to obtain empirical evidence from the effect of profitability, leverage and firm size on corporate value.

The research method used is descriptive and verification analysis. The population in this study are manufacturing companies the sub sector food and beverage listed on the Indonesia Stock Exchange for period 2014-2018. While the sample in this study was determined by purposive sampling method so that 11 sample companies were obtained. The classic assumption test, multiple linier regression analysis, determination coefficient and hypothesis test to partial and simultaneously.

The results of this study indicate that profitability significant effect on corporate value, leverage significant effect on corporate value and firm size have no significant effect on corporate value. Profitability, leverage and firm size significant effect on corporate value.
\end{abstract}

Keywords : corporate value;profitability; leverage, and firm size. 


\section{ENTREPRENEUR}

\section{Jurnal Bisnis Manajemen Dan Kewirausahaan}

\section{Program Studi Manajemen Fakultas Ekonomika dan Bisnis Universitas Majalengka}

Published every January and July e-ISSN : (Proses), p-ISSN: 2723-1941

Available online https://ejournal.unma.ac.id/index.php/entrepreneur

\section{PENDAHULUAN}

Di era globalisasi saat ini persaingan bisnis antar perusahaan sangat ketat serta tidak terlepas dari pengaruh sosial, politik, teknologi dan perkembangan lingkungan ekonomi. Oleh karena itu perusahaan harus lebih efektif dan efisien dalam melakukan kegiatan operasional perusahaan serta meningkatkan kinerja dan melakukan inovasi, sehingga dapat menjamin kehidupan perusahaan dan perusahaan dapat lebih unggul dari para pesaingnya (Ramadhitya, 2018). Tujuan utama dari perusahaan yang telah go public adalah meningkatkan kemakmuran pemegang saham dan untuk meningkatkan pertumbuhan perusahaan melalui peningkatan nilai perusahaan (Ramadhitya, 2018).

Pertumbuhan perusahaan yang mudah terlihat adalah adanya penilaian yang tinggi dari eksternal perusahaan terhadap aset perusahaan maupun terhadap pertumbuhan pasar saham. Nilai perusahaan merupakan harga yang sedia dibayar seandainya perusahaan tersebut dijual. Nilai perusahaan dapat tercermin melalui harga saham, semakin tinggi harga saham berarti semakin tinggi tingkat pengembalian kepada investor dan itu berarti semakin tinggi juga nilai perusahaan.

dalam $\begin{gathered}\text { Maksimalisasi nilai } \\ \text { meningkatkan }\end{gathered}$ kemakmahaan pemegang saham serta meningkatkan kinerja merupakan tujuan dan kewajiban dari perusahaan (Andini, 2014). Tujuan perusahaan dalam jangka panjang adalah mengoptimalkan nilai perusahaan dengan meminimalkan biaya modal perusahaan. Semakin tinggi nilai perusahaan akan menggambarkan semakin sejahtera pemilik perusahaan. Semakin baik kinerja keuangan suatu perusahaan pasti semakin baik pula nilai perusahaannya (Triagustina et al, 2014).

Optimalisasi nilai perusahaan dapat dicapai melalui pelaksanaan fungsi manajemen keuangan, dimana satu keputusan keuangan yang diambil akan mempengaruhi keputusan keuangan yang lainnya dan berdampak pada nilai perusahaan. Nilai perusahaan diharapkan dapat digunakan seminimal mungkin dengan memperhatikan jumlah modal yang diinvestasikan. Untuk perusahaanperusahaan yang berjalan dengan baik, rasio ini dapat mengalami peningkatan dengan menunjukan nilai pasar saham lebih besar dari nilai bukunya (Andini, 2014). Semakin tinggi rasio tersebut, perusahaan tentu semakin berhasil menciptakan nilai bagi pemegang sahamnya.

Nilai perusahaan menurut Fahmi Irham (2014:190), nilai perusahaan diperoleh dari hasil kualitas kinerja suatu perusahaan khususnya kinerja keuangan (financial performance), tentunya tidak bisa dikesampingkan dengan adanya dukungan dari kinerja non keuangan juga, sebagai sebuah sinergi yang saling mendukung pembentukan nilai perusahaan (coporate value). Bagi para pemegang saham, perusahaan menggambarkan nilai perusahaan termasuk seluruh komplesitas dan resiko dunia nyata. Nilai perusahaan pada dasarnya dapat diukur melalui beberapa aspek, salah satunya dengan harga pasar saham perusahaan, karena harga pasar saham mencerminkan penilaian investor secara keseluruhan atas setiap ekuitas yang dimiliki.

Nilai perusahaan pada sektor aneka industri mengalami penurunan dikarenakan saham sektor industri sedang anjlok. Sektor aneka industri membukukan kinerja hasil terburuk sepanjang 9 bulan pertama tahun 2019 dengan menurun sebesar 16,05\% 


\section{ENTREPRENEUR}

\section{Jurnal Bisnis Manajemen Dan Kewirausahaan}

Program Studi Manajemen Fakultas Ekonomika dan Bisnis Universitas Majalengka Published every January and July e-ISSN : (Proses), p-ISSN: 2723-1941 Available online https://ejournal.unma.ac.id/index.php/entrepreneur

dimana saham-saham industri tekstil dan garmen berkontribusi signifikan atas penurunan tersebut. (cnb.indonesia.com).

Berdasarkan latar belakang yang telah diuraikan dan fenomena-fenomena diatas, maka peneliti ingin melakukan penelitian guna mengetahui hasil yang sebenarnya terjadi dengan data yang relevan dalam penelitian yang berjudul PENGARUH PROFITABILITAS,

LEVERAGE DAN UKURAN
PERUSAHAAN TERHADAP NILAI
PERUSAHAAN PADA PERUSAHAAN
MAKANAN DAN MINUMAN YANG
TERDAFTAR DI BEI TAHUN 2014-
2018.

\section{Rumusan Masalah}

Berdasarkan pada uraian latar belakang, maka rumusan masalahnya sebagai berikut:

1. Bagaimana pengaruh profitabilitas terhadap nilai perusahaan.

2. Bagaimana pengaruh leverage terhadap nilai perusahaan.

3. Bagaimana pengaruh ukuran perusahaan terhadap nilai perusahaan.

4. Bagaimana pengaruh profitabilitas, leverage dan ukuran perusahaan terhadap nilai perusahaan.

\section{KERANGKA TEORITIS DAN HIPOTESIS}

Menurut Munawir (2014:33), Profitabilitas adalah menunjukan kemampuan perusahaan untuk menghasilkan laba selama periode tertentu. Profitabilitas suatu perusahaan diukur dengan kesuksesan perusahaan dan kemampuan menggunakan aktivanya secara produktif, dengan demikian profitabilitas suatu perusahaan dapat diketahui dengan memperbandingkan antara laba yang diperoleh dalam satu periode dengan jumlah aktiva atau modal perusahaan tersebut."

Menurut Kasmir (2016:151), leverage ratio merupakan rasio yang digunakan untuk mengukur sejauh mana aktiva perusahaan dibiayai dengan utang. Artinya berapa besar beban utang yang ditanggung perusahaan dibandingkan dengan aktivanya. Dalam arti luas dikatakan bahwa leverage digunakan untuk mengukur kemampuan perusahaan untuk membayar seluruh kewajibannya, baik jangka pendek ataupun jangka panjang apabila perusahaan dibubarkan (dilikuidasi).

Ukuran perusahaan merupakan besarnya aset yang dimiliki oleh suatu perusahaan. Ukuran perusahaan dilihat dari total aset yang dimiliki oleh perusahaan yang dapat digunakan untuk kegiatan operasi perusahaan. Semakin besar total aset yang dimiliki suatu perusahaan, semakin besar pula ukuran perusahaan. Semakin besar aset maka semakin besar pula modal yang ditanam, (Sujarweni, 2015:211).

Nilai perusahaan menurut Fahmi (2014:190), nilai perusahaan diperoleh dari hasil kualitas kinerja suatu perusahaan khususnya kinerja keuangan (financial performance), tentunya tidak bisa dikesampingkan dengan adanya dukungan dari kinerja non keuangan juga, sebagai sebuah sinergi yang saling mendukung pembentukan nilai perusahaan (coporate value).

\section{Hipotesis Penelitian}

Maka dari itu berdasarkan rumusan masalah dan pemaparan yang sudah dijelaskan penelitian, maka peneliti mengajukan hipotesis sebagai berikut: 


\section{ENTREPRENEUR}

Jurnal Bisnis Manajemen Dan Kewirausahaan

Program Studi Manajemen Fakultas Ekonomika dan Bisnis Universitas Majalengka Published every January and July e-ISSN : (Proses), p-ISSN: 2723-1941

Available online https://ejournal.unma.ac.id/index.php/entrepreneur

H1 : Profitabilitas berpengaruh signifikan terhadap nilai perusahaan.

$\mathrm{H} 2$ : Leverage berpengaruh signifikan terhadap nilai perusahaan.

H3 : Ukuran Perusahaan berpengaruh signifikan terhadap nilai perusahaan.

H4 : Profitabilitas, Leverage dan Ukuran Perusahaan berpengaruh signifikan terhadap nilai perusahaan.

\section{METODOLOGI PENELITIAN}

Metode analisis yang digunakan dalam penelitian ini adalah analisis deskriptif dan analisis verifikatif. Dalam penelitian ini, proksi yang digunakan untuk nilai perusahaan yaitu dengan menggunakan Tobin's $Q$ yang dinilai dapat memberikan informasi paling baik, karena dalam Tobin's Q memasukkan semua unsur utang dan modal saham perusahaan. Salah satu alternatif yang digunakan dalam menilai nilai perusahaan adalah dengan menggunakan Tobin's Q. Jika rasio Q diatas satu, ini menunjukkan bahwa investasi dalam aktiva menghasilkan laba yang memberikan nilai yang lebih tinggi daripada pengeluaran investasi, hal ini akan merangsang investasi baru. Jika rasio Q dibawah satu, investasi dalam aktiva tidaklah menarik.

$$
\begin{aligned}
Q= & \left(\left(\begin{array}{c}
\text { closing price } x \text { saham yang } \\
\text { beredar })+ \text { total }
\end{array}\right.\right. \\
& \frac{\text { hutang })}{}
\end{aligned}
$$

Sumber: Sri Mariyatni, 2017

Dalam penelitian ini rasio profitabilitas diukur dengan Return On Assets (ROA). Return On Assets merupakan suatu indikator keberhasilan manajemen dalam menghasilkan keuntungan yang sebesar besarnya bagi perusahaan. Return On Assets digunakan investor dalam memprediksi laba dan memprediksi risiko dalam investasi, sehingga memberikan dampak pada kepercayaan investor tehadap perusahaan.

ROA $=$ Laba bersih (Laba setelah pajak) $\times 100 \%$ Total Aset

Sumber: Irham Fahmi, 2018:82

Dalam penelitian ini rasio leverage diukur dengan rasio Debt to Equity Ratio, dengan rasio ini kita dapat mengetahui perbandingan antara seluruh hutang termasuk hutang lancar dengan seluruh ekuitas.

Ukuran perusahaan adalah suatu skala yang menentukan besar kecilnya perusahaan yang dapat dilihat dari nilai equity, nilai penjualan, jumlah karyawan dan nilai total aset perusahaan yang dimiliki, nilai pasar saham, dan rata-rata tingkat penjualan yang merupakan variabel konteks yang mengukur tuntutan pelayanan atau produk suatu organisasi. Ukuran perusahaan diproksikan dengan log total aktiva. Ukuran aktiva digunakan untuk mengukur besarnya perusahaan, ukuran aktiva tersebut diukur sebagai logaritma dari total aktiva.

Ukuran Perusahaan $=$ Ln Total Aset

Sumber : Fahmi Irham, 2018

\section{Populasi dan Sampel}

Populasi dalam penelitian ini adalah perusahaan manufaktur sub sektor makanan dan minuman yang terdaftar di Bursa Efek Indonesia (BEI) yang berjumlah 18 perusahaan. Teknik pengambilan sampel penelitian ini menggunakan purposive.

Setelah dilakukan penyeleksian sampel berdasarkan kriteria diperoleh 


\section{ENTREPRENEUR}

\section{Jurnal Bisnis Manajemen Dan Kewirausahaan}

\section{Program Studi Manajemen Fakultas Ekonomika dan Bisnis Universitas Majalengka} Published every January and July e-ISSN : (Proses), p-ISSN: 2723-1941 Available online https://ejournal.unma.ac.id/index.php/entrepreneur

sampel sebanyak 11 perusahaan, dengan periode pengamatan 5 (lima) tahun berturutturut dari tahun 2014-2018 sehingga diperoleh data sampel sebanyak 55 data perusahaan. analisis koefisien determinasi, dan uji hipotesis.

\section{HASIL DAN PEMBAHASAN}

\begin{tabular}{|c|c|c|c|c|c|c|c|c|c|c|}
\hline \multicolumn{11}{|c|}{ Coefficients $^{a}$} \\
\hline \multirow[t]{2}{*}{ Model } & \multicolumn{2}{|c|}{$\begin{array}{l}\text { Unstandardized } \\
\text { Coefficients }\end{array}$} & \multirow{2}{*}{\begin{tabular}{|c}
$\begin{array}{c}\text { Standardi } \\
\text { zed } \\
\text { Coefficie } \\
\text { nts }\end{array}$ \\
Beta
\end{tabular}} & \multirow[t]{2}{*}{$\mathrm{t}$} & \multirow[t]{2}{*}{ Sig. } & \multicolumn{3}{|c|}{ Correlations } & \multicolumn{2}{|c|}{ Collinearity Statistics } \\
\hline & $B$ & Std. Error & & & & $\begin{array}{l}\text { Zero- } \\
\text { order }\end{array}$ & Partial & Part & Tolerance & VIF \\
\hline (Constant) & .778 & .998 & & .780 & .439 & & & & & \\
\hline Profitabilitas & .216 & .017 & .809 & 12.639 & .000 & .905 & .871 & .652 & .650 & 1.539 \\
\hline Leverage & 1.040 & .274 & .201 & 3.798 & .000 & .387 & .470 & .196 & .953 & 1.049 \\
\hline $\begin{array}{l}\text { Ukuran } \\
\text { Perusahaan }\end{array}$ & -.049 & .034 & -.092 & -1.461 & .150 & -.587 & -.200 & -.075 & .668 & 1.498 \\
\hline
\end{tabular}

Sumber: Output SPSS 21, diolah sendiri (2020)

ANOVAa

\begin{tabular}{|rl|r|r|r|r|r|}
\hline Model & Sum of Squares & df & Mean Square & F & Sig. \\
\hline \multirow{2}{*}{1} & Regression & 386.141 & 3 & 128.714 & 108.236 & $.000^{\mathrm{b}}$ \\
& Residual & 60.649 & 51 & 1.189 & & \\
& Total & 446.790 & 54 & & & \\
\hline
\end{tabular}

a. Dependent Variable: Nilai Perusahaan

b. Predictors: (Constant), Ukuran Perusahaan, Leverage, Profitabilitas

Sumber: Output SPSS 21, diolah

sendiri $(2020$

\section{Pembahasan}

\section{Pengaruh Profitabilitas Terhadap Nilai} Perusahaan

Berdasarkan hasil analisis menunjukkan bahwa profitabilitas berpengaruh terhadap nilai perusahaan. Hasil penelitian ini tidak konsisten dengan hasil penelitian yang dilakukan oleh Khumairoh (2016), yang menyatakan bahwa profitabilitas tidak berpengaruh signifikan

Adapun pengujian terdiri dari uji asumsi klasik, analisis regresi berganda , terhadap nilai perusahaan, hal ini disebabkan karena besar kecilnya rasio profitabilitas yang dihasilkan oleh suatu perusahaan tidak akan mempengaruhi tinggi rendahnya nilai perusahaan apabila perusahaan tersebut tidak dapat mengelola keuangannya dengan baik. 


\section{ENTREPRENEUR}

\section{Jurnal Bisnis Manajemen Dan Kewirausahaan}

Program Studi Manajemen Fakultas Ekonomika dan Bisnis Universitas Majalengka Published every January and July e-ISSN : (Proses), p-ISSN: 2723-1941

Available online https://ejournal.unma.ac.id/index.php/entrepreneur

Sedangkan hasil penelitian ini konsisten dengan penelitian Meriyana Siahaan (2018) yang menyatakan bahwa profitabilitas berpengaruh signifikan terhadap nilai perusahaan, hal ini terjadi karena profitabilitas merupakan salah satu indikator keberhasilan perusahaan untuk dapat menghasilkan laba sehingga semakin tinggi profitabilitas maka semakin tinggi pula kemampuan perusahaan untuk menghasilkan laba bagi perusahaannya. Sehingga dapat dikatakan bahwa semakin tinggi rasio profitabilitas suatu perusahaan maka akan semakin tinggi pula nilai perusahaan tersebut.

Secara teoritis, menurut Irham Fahmi (2018) rasio profitabilitas mengukur efektivitas manajemen secara keseluruhan yang ditujukan oleh besar kecilnya tingkat keuntungan yang diperoleh dalam hubungannya dengan penjualan maupun investasi. Profitabilitas dapat diukur dengan return on assets (ROA), hal ini dapat memungkinkan perusahaan untuk membiayai investasi dari dana yang berasal dari sumber internal yang tersedia dalam laba ditahan, sehingga informasi dalam ROA akan menjadi nilai positif bagi investor dan dapat meningkatkan nilai perusahaan. Semakin tinggi kemampuan perusahaan dalam memperoleh laba, maka semakin besar return yang diharapkan investor, sehingga menjadikan nilai perusahaan menjadi lebih baik.

Hasil penelitian ini sesuai dengan teori tersebut yaitu menunjukkan bahwa profitabilitas mempengaruhi nilai perusahaan, hal ini disebabkan karena tingkat profitabilitas yang tinggi mencerminkan bahwa perusahaan mampu mengelola aset yang dimiliki perusahaan dengan baik untuk menghasilkan laba salah satunya melalui penjualan yang tinggi,
Profitabilitas yang tinggi menjadi sinyal positif bagi reaksi pasar sehingga dapat meningkatkan harga saham suatu perusahaan, meningkatnya harga saham dipasar modal berarti meningkat pula nilai perusahaan di mata investor. Dengan demikian, semakin tinggi rasio profitabilitas maka akan semakin baik posisi perusahaan yang berarti semakin besar kemampuan perusahaan untuk menutupi investasi yang digunakan.

\section{Pengaruh Leverage Terhadap Nilai Perusahaan}

Berdasarkan hasil analisis menunjukan bahwa leverage berpengaruh terhadap nilai perusahaan. Hasil penelitian ini konsisten dengan penelitian Khumairoh (2016) yang menyatakan bahwa leverage berpengaruh signifikan terhadap nilai perusahaan, hal ini terjadi karena perusahaan mampu dalam melunasi utang-utang jangka panjangnya sehingga dapat dikatakan penggunaan leverage mampu meningkatkan nilai perusahaan. Hal ini dikarenakan dengan leverage atau utang yang tinggi perusahaan akan memiliki kesempatan untuk mendapat laba yang lebih besar pula.

Sedangkan hasil penelitian ini tidak konsisten dengan hasil penelitian yang dilakukan Meriyana Siahaan (2018) yang menyatakan bahwa leverage tidak berpengaruh signifikan terhadap nilai perusahaan, hal ini disebabkan karena dengan leverage atau utang yang tinggi akan berdampak pada nilai perusahaan yang rendah karena akan membuat investor maupun calon investor kurang percaya untuk menanamkan modalnya kepada perusahaan tersebut. 


\section{ENTREPRENEUR}

\section{Jurnal Bisnis Manajemen Dan Kewirausahaan}

Program Studi Manajemen Fakultas Ekonomika dan Bisnis Universitas Majalengka Published every January and July e-ISSN : (Proses), p-ISSN: 2723-1941 Available online https://ejournal.unma.ac.id/index.php/entrepreneur

Secara teoritis, menurut Kasmir (2014) leverage merupakan rasio yang digunakan untuk mengukur sejauh mana aktivitas perusahaan dibiayai dengan hutang. Leverage dapat diukur dengan debt to equity ratio (DER), leverage dapat dipahami sebagai penaksir dari resiko yang melekat pada suatu perusahaan. Artinya, leverage yang semakin besar menunjukan resiko investasi yang semakin besar pula. Perusahaan dengan rasio leverage yang rendah memiliki resiko leverage yang lebih kecil. Dengan tingginya rasio leverage menunjukan bahwa perusahaan tidak solvabel, artinya total hutangnya lebih besar dibandingkan dengan total asetnya yang akan menurunkan nilai perushaaan (Ernawati dan Widyawati, 2015:4).

Keputusan pendanaan (hutang) yang berkaitan dengan pemilihan sumber dana baik yang berasal dari eksternal maupun dari internal perusahaan sangat mempengaruhi nilai perusahaan. Sumber dana dari internal berasal dari laba ditahan dan depresiasi, sedangkan dana yang diperoleh dari sumber eksternal adalah dana yang berasal dari kreditur dan pemilik. Pemenuhan kebutuhan dana yang berasal dari kreditur merupakan utang bagi perusahaan atau disebut dengan metode pembelanjaan utang.

Hasil penelitian ini tidak sesuai dengan teori tersebut yaitu menunjukkan bahwa leverage mempengaruhi nilai perusahaan, hal ini disebabkan karena dalam penelitian ini, secara rata-rata data leverage perusahaan termasuk kedalam kategori tinggi, akan tetapi data empiris yang didapat dari penelitian ini nilai leverage masih berada dibawah batas wajar, sehingga dapat dikatakan bahwa perusahaan mampu mengelola utang dengan baik dan mampu melunasi utang-utang jangka panjangnya, dapat dikatakan penggunaan leverage berkontribusi didalam meningkatkan nilai perusahaan. Hal tersebut akan mempengaruhi tingkat kepercayaan investor terhadap perusahaan dan akan mempengaruhi nilai perusahaan.

\section{Pengaruh Ukuran Perusahaan Terhadap Nilai Perusahaan}

Berdasarkan hasil analisis menunjukan bahwa ukuran perusahaan tidak berpengaruh terhadap nilai perusahaan. Hasil penelitian ini tidak konsisten dengan hasil penelitian yang dilakukan Khumairoh (2016) yang menyatakan bahwa ukuran perusahaan memiliki pengaruh signifikan terhadap nilai perusahaan, hal ini terjadi karena semakin besar ukuran perusahaan maka akan semakin mudah perusahaan memperoleh sumber pendanaan yang dapat dimanfaatkan untuk mencapai tujuan perusahaan. Ukuran perusahaan yang besar menunjukan perusahaan mengalami perkembangan sehingga investor akan merespon positif dan nilai perusahaan akan meningkat. Sedangkan hasil penelitian ini konsisten dengan penelitian Gilang Kemal Ramadhitya dan Vaya Juliana Dillak (2018), yang menyatakan bahwa ukuran perusahaan tidak berpengaruh signifikan terhadap nilai perusahaan hal ini terjadi karena bahwa tinggi atau rendahnya ukuran perusahaan tidak mempengaruhi nilai perusahaan, karena ukuran perusahaan yang besar belum tentu bisa menjamin nilai perusahaannya tinggi, karena perusahaan besar mungkin belum 


\section{ENTREPRENEUR}

\section{Jurnal Bisnis Manajemen Dan Kewirausahaan}

\section{Program Studi Manajemen Fakultas Ekonomika dan Bisnis Universitas Majalengka}

Published every January and July e-ISSN : (Proses), p-ISSN: 2723-1941

Available online https://ejournal.unma.ac.id/index.php/entrepreneur

berani melakukan investasi baru terkait dengan ekspansi, sebelum kewajibankewajibannya (utang) sudah terlunasi. Hal ini juga menunjukkan besar kecilnya perusahaan tidak akan berpengaruh dengan besar kecilnya nilai perusahaan.

Secara teoritis, menurut Hery (2016) menyatakan bahwa semakin besar ukuran perusahaan maka ada kecenderungan lebih banyak investor yang menaruh perhatian pada perusahaan. Hal ini disebabkan karena perusahaan yang besar cenderung memiliki kondisi yang lebih stabil. Kestabilan tersebut mampu menarik investor untuk memiliki saham perusahaan tersebut dan kondisi tersebut menjadi penyebab atas naiknya harga saham perusahaan di pasar modal.

Hasil penelitian ini tidak sesuai dengan teori tersebut yang menunjukkan bahwa ukuran perusahaan tidak berpengaruh signifikan terhadap nilai perusahaan. Hal ini disebabkan karena ukuran perusahaan yang besar belum bisa menjamin nilai perusahaannya tinggi, karena perusahaan besar mungkin belum berani melakukan investasi baru terkait dengan ekspansi, sebelum kewajiban-kewajibannya (utang) sudah terlunasi. Walaupun ukuran perusahaannya besar akan tetapi perusahaan tersebut tidak maksimal didalam mengelola sumber pendapatan atau profitabilitasnya dan tidak bisa mengelola kinerja keuangan perusahaannya dengan baik. Sehingga tinggi atau rendahnya ukuran perusahaan tidak mempengaruhi nilai perusahaan.

Perusahaan yang memiliki total aset yang besar maka pihak manajemen akan lebih leluasa dalam mempergunakan aset yang ada dalam perusahaan tersebut, kebebasan yang dimiliki manajemen ini sebanding dengan kekhawatiran pemilik perusahaan atas asetnya dan jumlah aset yang besar akan menurunkan nilai perusahaan. Selain itu dalam penelitian ini, ukuran perusahaan bukan merupakan pertimbangan bagi investor dalam berinvestasi, ukuran perusahaan dinilai dari total aset yang dimiliki perusahaan untuk kegiatan operasionalnya.

\section{Pengaruh Profitabilitas, Leverage dan Ukuran Perusahaan Terhadap Nilai Perusahaan}

Berdasarkan hasil analisis menunjukan bahwa profitabilitas, leverage dan ukuran perusahaan berpengaruh terhadap nilai perusahaan. Hasil penelitian ini konsisten dengan hasil penelitian Khumairoh (2016) yang menyatakan bahwa profitabilitas, leverage dan ukuran perusahaan secara simultan atau bersamasama berpengaruh signifikan terhadap nilai perusahaan.

Dari penelitian ini diketahui bahwa nilai koefisien determinasi ( $\mathrm{R}$ square) sebesar 86,49\%. Hal ini berarti 86,49\% pengaruh nilai perusahaan dapat dijelaskan oleh variabel independen tersebut yaitu profitabilitas, leverage dan ukuran perusahaan. Sedangkan sisanya $13,51 \%$ dijelaskan oleh variabel lain yang tidak diteliti atau dijadikan variabel independen pada penelitian ini.

Hasil penelitian ini menunjukkan bahwa kenaikkan atau penurunan dari profitabilitas, leverage dan ukuran perusahaan akan mempengaruhi nilai perusahaan. Dengan profitabilitas, leverage dan ukuran perusahaan berpengaruh terhadap nilai perusahaan, maka akan memberikan sinyal kepada investor dalam menilai sebuah perusahaan. Profitabilitas yang tinggi mencerminkan kemampuan perusahaan dalam menghasilkan keuntungan yang tinggi bagi pemegang saham. Semakin besar keuntungan yang diperoleh, maka semakin besar pula kemampuan perusahaan 


\section{ENTREPRENEUR}

\section{Jurnal Bisnis Manajemen Dan Kewirausahaan}

Program Studi Manajemen Fakultas Ekonomika dan Bisnis Universitas Majalengka Published every January and July e-ISSN : (Proses), p-ISSN: 2723-1941 Available online https://ejournal.unma.ac.id/index.php/entrepreneur

untuk membayarkan dividennya dan hal ini berdampak pada kenaikkan nilai perusahaan. Tingginya tingkat laba yang dihasilkan, berarti prospek untuk menjalankan operasinya di masa depan juga tinggi, sehingga nilai perusahaan yang tercermin dari harga saham perusahaan akan meningkat pula. Leverage dan nilai perusahaan yang tinggi menyebabkan penggunaan utang dalam perusahaan meningkat dan kemuadian akan mempengaruhi nilai perusahaan.

Selain profitabilitas dan leverage, ukuran perusahaan juga berdampak pada kepercayaan investor untuk menanamkan modal terhadap perusahaan tersebut. Ukuran perusahaan yang besar akan lebih mudah untuk dipercaya oleh investor sehingga dapat memperoleh sumber dana yang besar baik bersifat internal maupun eksternal.

Selain itu, dengan semakin besar ukuran perusahaan, maka ada kecenderungan lebih banyak investor yang menaruh perhatian kepada perusahaan tersebut. Hal ini disebabkan karena perusahaan yang besar cenderung memiliki kondisi yang lebih stabil dari tahun ke tahun utamanya dalam return saham kepada investor. Ukuran perusahaan yang besar menunjukan perusahaan mengalami perkembangan sehingga investor akan merespon positif dan nilai perusahaan akan meningkat. Oleh karena itu dengan tingginya profitabilitas, pengelolaan utang yang baik dan optimal serta ukuran perusahaan yang tinggi akan meningkatkan nilai perusahaan.

\section{SIMPULAN DAN IMLIKASI}

Berdasarkan hasil penelitian dan analisis data yang dilakukan, maka dapat diperoleh kesimpulan sebagai berikut:

1. Profitabilitas berpengaruh signifikan terhadap nilai perusahaan. Artinya bahwa semakin tinggi profitabilitas yang didapat maka semakin tinggi pula nilai perusahaannya. Hal ini dikarenakan tingkat profitabilitas yang tinggi mencerminkan bahwa perusahaan mampu mengelola aset yang dimiliki perusahaan dengan baik untuk menghasilkan laba salah satunya melalui penjualan yang tinggi.

2. Leverage berpengaruh signifikan terhadap nilai perusahaan. Artinya bahwa semakin tinggi leverage maka semakin tinggi pula nilai perusahaannya. Hal ini dikarenakan dalam penelitian ini, perusahaan mampu dalam melunasi utang-utang jangka panjangnya sehingga dapat dikatakan penggunaan leverage mampu meningkatkan nilai perusahaan.

3. Ukuran perusahaan tidak berpengaruh signifikan terhadap nilai perusahaan. Artinya bahwa tinggi atau rendahnya ukuran perusahaan tidak akan mempengaruhi nilai perusahaannya. Hal ini dikarenakan ukuran perusahaan yang besar belum tentu bisa menjamin nilai perusahaannya tinggi.

4. Profitabilitas, leverage dan ukuran perusahaan berpengaruh signifikan terhadap nilai perusahaan. Artinya bahwa semakin tinggi profitabilitas, leverage dan ukuran perusahaan maka semakin tinggi pula nilai perusahaan, karena dengan tingginya profitabilitas, pengelolaan utang yang baik dan optimal serta ukuran perusahaan yang 


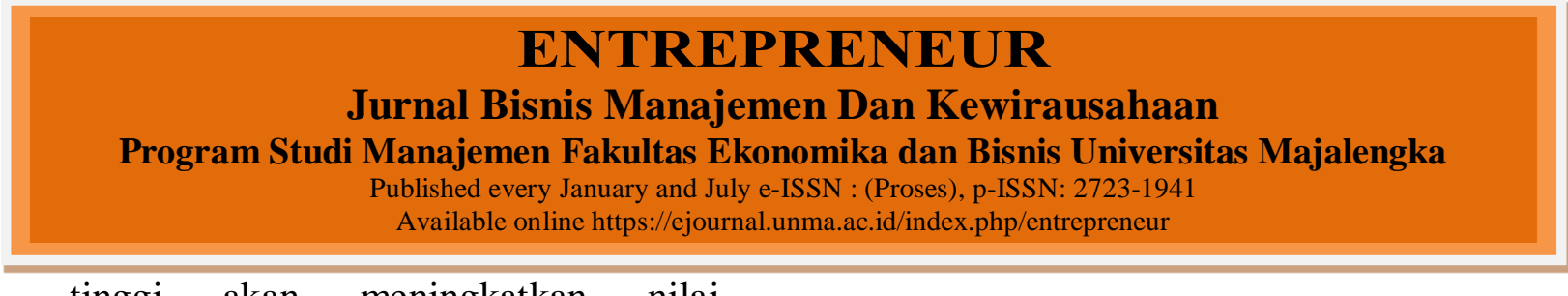

tinggi akan meningkatkan nilai perusahaan.

\section{DAFTAR PUSTAKA}

Andini. 2015. Analisis Pengaruh Struktur

Modal, Profitabilitas, Kebijakan

Deviden dan Size Terhadap Nilai

Perusahaan. Jurnal Ekonomika dan

Bisnis Universitas Diponegoro

Semarang.

Ernawati dan Widyawati. 2015. Pengaruh

Profitabilitas, Leverage dan Ukuran

Perusahaan Terhadap Nilai

Perusahaan. Vol. 4 Jurnal Ilmu \& Riset

Akuntansi.

Fahmi Irham. 2014. Analisis Laporan Keuangan. Alfabeta. Bandung

Vaya Juliana Dillak, 2018. Pengaruh

Profitabilitas, Leverage, Ukuran

Perusahaan \& Keputusan Investasi

Terhadap Nilai Perusahaan. Vol. 5 No.

3 Jurnal Ilmu Akuntansi

Hery. 2016. Analisis Laporan Keuangan. Jakarta: Grasindo.

Kasmir. 2016. Analisis Laporan Keuangan. Jakarta: Raja Grafindo Persada

Khumairah, et.al. 2016. Pengaruh Leverage, Profitabilitas dan Ukuran Perusahaan Terhadap Nilai Perusahaan. Jurnal Ilmu Akuntansi.

Meriyana Siahaan. 2016. Pengaruh Leverage dan Profitabilitas Terhadap Nilai Perusahaan. Vol. 2 No. 2 Jurnal Akuntansi Keuangan.

Sri Mariyatni. 2017. Analisis Rasio Keuangan untuk Menilai Perusahaan Di Bursa Efek Indonesia. Vol. 23 No. 1 Jurnal Ilmiah Manajemen \& Akuntansi.

Sujarweni, V. Wiratna. 2015. Akuntansi Manajemen. Yogyakarta: Pustaka Baru Press. 